\title{
Challenges in surveillance and response
}

\author{
Laurence Slutsker \\ From Challenges in malaria research \\ Basel, Switzerland. 10-12 October 2012
}

Surveillance in the context of malaria elimination will needs to shift from measuring reductions in morbidity and mortality to detecting infections (with or without symptoms). The malaria elimination surveillance research and development agenda needs to develop tools and strategies for active and prompt detection of infection. The capacity to assess trends and respond without delay will need to be developed, so that surveillance itself becomes an intervention. Research is needed to develop sensitive field tests that can detect low levels of parasitaemia and/ or evidence of recent infection. Examples of recent work on surveillance and response issues in several African countries will be discussed to illustrate approaches in active case detection and case investigations, cell phone reporting and response, and strategies to access mobile populations.

Published: 15 October 2012

doi:10.1186/1475-2875-11-S1-03

Cite this article as: Slutsker: Challenges in surveillance and response.

Malaria Journal 2012 11(Suppl 1):O3.

Submit your next manuscript to BioMed Central and take full advantage of:

- Convenient online submission

- Thorough peer review

- No space constraints or color figure charges

- Immediate publication on acceptance

- Inclusion in PubMed, CAS, Scopus and Google Scholar

- Research which is freely available for redistribution 